\title{
NULIDADES, PREJUízo E CONSTITUIÇÃO: Analise dos Novos Horizontes Construídos pela Doutrina e pelo Supremo Tribunal Federal
}

\author{
Diego Prezzi Santos ${ }^{1}$ \\ Faculdade Catuaí em Cambe, Paraná
}

http://dx.doi.org/10.5209/rev_NOMA.2014.v42.n2.48783

\begin{abstract}
Resumo.- O presente artigo científico buscou esclarecer sobre a nova compreensão que o Supremo Tribunal Federal tem sobre o sistema de nulidades processuais penais pósconstitucionais. Demonstrou-se que o paradigma de nulidades anterior à Constituição, baseado somento no critério do prejuízo e à sua prova, foi relativizado e a norma constitucional construiu um critério de validade do Devido Processo como ente para aferição de nulidade processual penal. Para isso foram examinadas as mais relevantes decisões do STF sobre o tema e também as considerações doutrinárias que dão conta que as nulidades absolutas se regem pelo prejuízo presumido ou prejuízo impossível de ser provado.
\end{abstract}

Palavras chave.- Nulidades; Processo Penal; Prejuízo Presumido; Princípios; Supremo Tribunal Federal.

\section{INTRODUÇÃO}

Sem reinvindicar qualquer pecha de que está sendo exposta a "única verdade" (pois seria ilógico, irresponsável e estúpido), mas também evitando simplesmente repetir, foi exposto no presente artigo científico estudo que segue na busca de revelar um ponto de vista que tire o intérprete dos nove círculos $^{2}$ do processo penal cotidiado e leve-o, ao menos, a atingir o Anteinferno de um processo penal constitucional.

No artigo científico presente, busca-se demonstrar que o Supremo Tribunal Federal alterou o foco de sua interpretação sobre o sistema de nulidades e, para que isso fique claro, inicialmente, prima-se por elucidar o que é o sistema de nulidades para a maioria da jurisprudência.

Demonstra-se a existência de vícios no sistema de nulidades, os quais convergem para uma situação de total incompreensão de sentido e de intenção dos julgadores. Verificar-se-à que tais vícios são, em parte, fruto de uma compreensão errada e anterior ao novo substrato constitucional garantista.

\footnotetext{
1 Mestrando em Direitos da Personalidade pelo Centro Universitário de Maringá. Pósgraduando em Direito e Processo Penal pela Universidade Estadual de Londrina. Graduado pela Universidade Estadual de Londrina. Professor de Direito Penal II e Direito Penal V na Faculdade Catuaí em Cambe, Paraná. Advogado em Londrina, Paraná.

${ }^{2}$ Dante Alighieri. A Divina Comédia: Inferno, Purgatório e Paraíso. Tradução e notas de Ítalo Eugênio Mauro. Em português e italiano (original). Editora 34, São Paulo, 1999.
} 
No tópico seguinte, será abordado o fato de que a Constituição Federal de 1988 alterou todo o foco valorativo de criação e de interpretação normativa, impondo que se compreenda o processo penal sob a égide da Dignidade e do Devido Processo como entes que se buscam.

Diante deste novo contexto, a autoaplicação dos princípios e das garantias o que importa de fato é o nível de efetividade que se confere aos princípios e não o balanço entre finalidade e prejuízo do ato.

No tópico que segue, verificou-se a criação de um alinhamento doutrinário compatível com a Constituição Federal, seus princípios e as garantias previstas. Anota-se que se fez referência as qualidades das garantias e a sua finalidade de guia processual devido.

No tópico de conclusão, será exposto um tópico sobre nulidades e prejuízo, constatando que parte da jurisprudência acredita ser necessário que nas nulidades absolutas sempre se demonstre o prejuízo. Por força de uma interpretação constitucional do devido processo, levou-se ao trabalho decisões e entendimentos de que nem sempre é necessário se provar o prejuízo.

Serão alinhavados primeiros precedentes do Supremo sobre casos em que não há possibilidade de se provar o prejuízo. Posteriormente, aborda-se os julgados nos quais o foco é o fato de o prejuízo ser presumido e tal presunção ser agravada ou criada pela condenação do acusado.

Tentar-se-à lançar mão das jurisprudências e de parte dos votos dos ministros para se comprovar a alteração de foto interpretação e criativo visto no primeiro capítulo do trabalho na busca de uma conformidade democrática do processo.

\section{A VISÃO EMPOEIRADA SOBRE O SISTEMA DE NULIDADES PROCESSUAIS PENAIS}

O sistema de nulidades encontra-se disposto no atual Código de Processo Penal nos arts. 563 a 573, os quais elucidam diversas fórmulas e requisitos a serem adotados pelo aplicador do direito quando se verifica o descumprimento de algum tipo processual estabelecido pelo legislador ordinário ou constitucional.

A finalidade de se estabelecer nulidades processuais decorre da importância que existe no cumprimento das formas em um processo que lida com bens jurídicos tão relevantes como é o criminal.

O processo não pode seguir de qualquer forma, os atos não podem ser praticados e seguidos sem uma regulamentação, devendo existir o cumprimento dos tipos processuais.

Tal situação ganha importância quando se percebe que a Constituição Federal fundamenta diversas fórmulas contidas no CPP, as quais, por imperativo de hierárquia valorativa, não podem ser desrespeitadas.

No entanto, por diversas razões não mais se compreende a forma como uma expressão de um valor importante previsto na Constituição e esse 
entendimento causa forte preconceito com as nulidades, as quais são vistas como uma forma de se buscar impunidade ou mesmo formalismo exagerado.

Detectam-se problemas graves, sendo o primeiro o da compreensão de que o sistema de nulidades leva a impunidade, o que subverte totalmente a finalidade real, que é a de garantir a possibilidade de justiça por força do Devido Processo Legal.

Uma análise feita mostra que diversos autores sequer verificam essa hipótese em suas obras. Entretanto, muitos juristas ${ }^{3}$ e jornalistas disseminam para opinião pública esse vínculo entre impunidade e ato nulo, contaminando os julgadores e os acusadores públicos.

Em uma entrevista concedida ao site Consultor Jurídico, o advogado Celso Vilardi ${ }^{4}$ trata da relação entre descumprimento da lei pelo Estado (como é o caso das várias nulidades) e a impunidade, deixando clara a posição de harmonia que deve existir:

ConJur - Uma investigação longa anulada por uma irregularidade não é frustrante levando-se em conta o gasto público com a persecução penal? Celso Vilardi - Claro que é. E isso acaba gerando impunidade. Mas existem vários erros para se chegar a esse ponto. Em primeiro lugar, a falta de legalidade nas investigações. Se ela fosse evitada, não se frustraria a população, porque não se chegaria a provas nulas. Além disso, há uma praxe na revelação desses dados em um momento inicial da apuração. Isso acaba chegando à sociedade no primeiro minuto de jogo, antes de se ter uma discussão sobre a licitude de tudo o que foi feito. O resultado é a criação de uma expectativa. Se as investigações não vazassem documentos sigilosos de forma ilegal, não haveria esse problema. Vazamentos acontecem em quase todas as operações. Só que quando o caso começa a ser julgado, pode ter uma prova ilícita, uma história que não é verdadeira, uma evidência que demonstre que aquela acusação era inteiramente falsa.

O cumprimento da legislação pelo Estado nos processos penais deve(ria) ser evidente e regular, no entanto, não é o que ocorre.

O segundo vício do sistema de nulidades parte da interpretação excessiva que brotou da tentativa de tirar formalidades dos proceso penal, mas que descambou a uma concepção de que a maioria dos atos previstos na lei são atos com excesso de formalismos.

\footnotetext{
${ }^{3}$ ARAS, Vladimir. O Bilhete premiado. Disponível em: http://blogdovladimir.wordpress.com/2011/02/05/o-bilhete-premiado. Acesso em 07/02/2011. VIANA, Jorge Candido C.S. O Processo Penal no campo das nulidades. Disponível em http://osramosdodireito.blogspot.com/2011/05/o-processo-penal-no-campo-das-nulidades.html. Acesso em 06/05/2011.

${ }^{4}$ VILARDI, Celso. Advogado não absolve, defende. Disponível em: http://www.conjur.com.br/2011-mai-22/entrevista-celso-vilardi-advogado-criminalista-professorfgv-sp. Acesso em 01/06/2011.
} 
Consoante as formalidades, anota-se que as formas previstas na Lei são formas-garantia que têm vultosa relevância para que exista um processo constitucionalmente devido. Muitas vezes, porém, o desrespeito constatado não é à fórmula legal e sim a um princípio ou a uma ou garantia (ou princípioqualificado).

Ainda assim, em exercícios de hermenêutica com premissas confusas, o processo segue como se nada tivesse ocorrido de mais grave, mesmo quando o ato praticado tenha levado a ser vítima um princípio ou garantia.

Neste passo, cumpre adotar o que foi dito por Eduardo Jorge Couture quando se propôs a estudar o sistema e os objetivos das nulidades processuais:

la nulidad consiste em el apartamiento de esse conjunto de formas necesarias establecidas por la ley. Este primer intento de fijar el sentido de la nulidad procesal, demustra que no es cosa atinente al contenido mismo del derecho sino a sus formas; no es um error em los fines de justicia queridos por la ley, sino de los medios dados para obtener esos fines de bien y de justicia ${ }^{5}$.

Não se pode(ria) vislumbrar o sistema de nulidades de outra forma que não seja a de proteger a Constituição e os Princípios e, assim, permitir que se busque Justiça por meio de Devido Processo Legal, até porque as formalidadades previstas na lei, decorrentes do Princípio do Devido Processo, não são letras vazias e sim uma proteção ao procedimento mais importante.

Sergio Gabriel Torres ao falar do processo penal, menciona que pela finalidade deste ramo, sob pena de ilegalidade do ato, este deve ser praticado segundo alguns requisitos:

El proceso, por su propia naturaleza, está compuesto de una serie de actos denominados "procesales" cuya función es lograr, a través de un conjunto concatenado lógico y jurídico, su finalidad, es decir, la obtención de un pronunciamiento jurisdiccional que decida un determinado conflicto y que, eventualmente, promueva su ejecución. Ahora bien, el acto procesal como especie dentro del género acto jurídico, debe adecuar su cumplimiento a determinados requisitos, ya que de lo contrarío, su accionar seria ilegal y por ello, deberá ser apartado del proceso ${ }^{6}$.

A forma prevista em legislação, assim, não é feita sem fundamento e sim na tentativa do legislador de conferir amparo legal aos princípios processuais constitucionais estabelecidos.

\footnotetext{
${ }^{5}$ COUTURE, Eduardo Jorge. Fundamentos del derecho procesal civil. $4^{\circ}$ ed. Buenos Aires: Euros, 2002, p. 304-305.

${ }^{6}$ TORRES, Sergio Gabriel. Nulidades em el proceso penal. $2^{\mathrm{a}}$ ed. actu. y ampl. Buenos Aires:
}

Ad hoc, 1993, p. 28. 
Assim, a visão de que a nulidade é vinculada a uma formalidade excessiva e desnecessária deve ser afastada por força da natureza do sistema, que é de proteção.

Já o terceiro e mais grave dos problemas é um óbice de interpretação que tem origem no art. 563 do Código de Processo Penal e diz respeito ao conceito de prejuízo e sua possibilidade de prova. Fato interessante é que os primeiros equívocos existentes no sistema incidem e contribuem diretamente para este terceiro.

Tal circunstância de convergência decorre do fato de que, ao se interpretar a nulidade como um benefício ao acusado, a possibilidade de se enxergar em um fato com grave prejuízo um prejuízo leve - ou inexistente - aumenta.

Interessante notar que a observação retirada da obra Animal Moral de Robert Wright:

O cérebro é como um bom advogado: dado um conjunto de interesses a defender, ele se põe a convencer o mundo de sua correção lógica e moral, independentemente de ter qualquer uma das duas. Como um advogado, o cérebro humano quer vitória, não verdade; e, como um advogado, ele é muitas vezes mais admirável por sua habilidade do que por sua virtude ${ }^{7}$.

Na lição de Franco Cordero, verifica-se com acerto o "primato dell'ipotesi sui fatti gerador de quadri mentali paranoid"8, isto é, faz-se uma hipótese, opta-se por ela e, após tal situação, existe uma busca desesperada por subterfúgios necessários e mais fáceis que possam concluir pela sua versão dos fatos.

É quadro paranóico de tentativa de recorrente autolegitimação, que irá refletir no conceito de nulidade e no cerne de prejuízo. Portanto, inegável que quando se interpreta que tal sistema é um benefício ao acusado, haverá um julgamento mais tendente a não reconhecer a invalidade.

O segundo problema tem reflexo direto nessa compreensão

Aury Lopes Jr., apresenta questionamento importante sobre o tema, expondo grande parte das questões que se pretende trabalhar:

Além da imprecisão em torno do que seja "prejuízo", há um agravamento da questão no momento em que se exige que a parte prejudicada (geralmente, a defesa, por evidente) faça prova dele. Como se faz essa prova? Ou ainda, o que se entende por

\footnotetext{
${ }^{7}$ Uma Idéia Perigosa. Disponível em:

http://www1.folha.uol.com.br/colunas/helioschwartsman/923931-uma-ideia-perigosa.shtml. Acesso em 02/06/2011.

${ }^{8}$ CORDERO, Franco. Guida alla Procedura Penale.Torino: Utet, 1986, p. 51.
} 
prejuízo? Somente a partir disso é que passamos para a dimensção mais problemática: como demonstrá-lo? ${ }^{9}$

O mesmo autor aponta uma conclusão terrível para a segurança jurídica, pois a "incerteza é absolutamente incompatível com o processo penal contemporâneo". ${ }^{10}$ Exatamente por não existir precisão semântica, a crítica a expressão prejuízo feita por Jacinto Nelson de Miranda Coutinho é acertada:

prejuízo, em sendo um conceito indeterminado (como tantos outros dos quais esta prenhe a nossa legislação penal), vai encontrar seu referencial semântico naquilo que entender 0 julgador; e aí não é difícil perceber, manuseando as compilações de julgados, que não raro expressam decisões teratológicas. ${ }^{11}$

A imprecisão de sentido do conceito permite uma série de recursos para que se compreenda por declarar ou não uma nulidade processual, causando situação desconforto e de manipulação discursiva, a qual agrave os problemas anteriores, porque ao examinar uma nulidade o magistrado por conceber que aquele sujeito não deve ser "beneficiado" e que o ato é muito formal e isso não é alinhado ao novo processo de inclinação célere.

Esse conjunto de defeitos que paíra sobre a galáxia das nulidades nada mais é do que uma expressão do recorrente caos existente no universo do processo penal.

Permite-se uma situação em que a maioria imensa dos atos praticados em desconformidade com a lei ou a própria Constituição seja convalidada em razão de ser o modelo deôntico muito formalista, da atipicidade não causar, no entendimento do magistrado, prejuízo ou ainda quando este não é cabalmente provado.

Essa facilidade de convalidação é o quarto dos problemas do sistema de nulidades, posto que se nenhum ato é uma violação muito grave, é possível que seja considerada nulidade relativa e, logo, se não arguida no momento propício haja convalidação ou ainda, não havendo demonstração do prejuízo, não haverá motivo, no entendimento dos julgadores, para se reconhecer invalidade.

Se junta a essa confusão, a tormentosa distinção entre nulidade relativa e absoluta, visto que existem entendimentos de que as relativas dizem respeito aos interesses privados no processo penal quando, de fato, "A proteção do réu é pública, porque públicos são os direitos e garantias constitucionais que o tutelam". 12

\footnotetext{
${ }^{9}$ LOPES JR., Aury. Direito Processual Penal e sua Conformidade Constitucional. V. 2. Rio de Janeiro: Lumen Juris, 2009, p. 389.

${ }^{10}$ LOPES JR., Aury. Direito Processual Penal e sua Conformidade Constitucional. V. 2. Rio de Janeiro: Lumen Juris, 2009, p. 389.

${ }^{11}$ COUTINHO, Jacinto Nelson de Miranda. Introdução aos Princípios Gerais do Processo Penal Brasileiro. Revista de Estudos Criminais. Porto Alegre: Nota dez, n. 01, p. 44.

${ }_{12}$ LOPES JR., Aury. Direito Processual Penal e sua Conformidade Constitucional. V. 2. Rio de Janeiro: Lumen Juris, 2009, p. 391.
} 
À luz do novo processo penal constitucional, percebe-se uma grave crise de segurança constitucional em relação ao processo criminal e as garantias da pessoa. Uma luz surgiu, todavia, no Supremo Tribunal Federal pautada numa concepção constitucionalista do processo.

\section{O PARADIGMA CONSTITUCIONAL}

A Carta Democrática é construída sobre um valor fundante bastante amplo, que é o da Dignidade Humana contida no art. $1^{\circ}$, inciso III.

Além de tal núcleo, existem princípios e garantias diversas que se alinham a finalidade dignificante, como a Ampla Defesa, o Devido Processo, a Fundamentação das Decisões, a Publicidade.

As garantias, como princípios qualificadados que são, tem o condão de assegurar o cumprimento e a fruição de direitos e princípios estabelecidos como fundamentais até pelo que se enxerga no $\$ 1^{\circ}$ do art. $5^{\circ}$ da Constituição Federal.

A inauguração de um Estado Democrático de Direito ocorreu com a nova Carta consagradora de preceitos antropocentricos que deixaram de ser recomendações e se tornaram o núcleo do Ordenamento Jurídico:

As constituições promulgadas nos últimos decênios se caracterizam pela presença no elenco de suas normas de instâncias de garantia de prerrogativas individuais, e concomitantemente de instâncias que traduzem imperativos de tutelas de bens transindividuais ou coletivos. Ou seja: os princípios do Rechsstaats e, ao mesmo tempo do Sozialstaats. Os primeiros configuram-se em preceitos asseguradores dos direitos humanos e da cidadania. Os segundos se fazem presentes na tutela dos valores sociais $^{13}$.

Vista a lição de Luis Luisi, cumpre expor que essa presença das garantias realmente alterou todo o foco interpretativo e normativo, tanto é que Lenio Streck fala sobre uma compreensão constitucional que se amplia para influenciar todos os leis, atos e princípios do Direito:

Constituição enquanto detentora de uma força normativa e compromissária, pois é exatamente a partir da compreensão desse fenômeno que poderemos dar sentido à relação Constituição-Estado-Sociedade. Mais do que isso, é do sentido que temos de Constituição que dependerá o processo de interpretação dos textos normativos do sistema ${ }^{14}$.

\footnotetext{
${ }^{13}$ LUISI, Luiz. Os Princípios Constitucionais Penais. $2^{\circ}$ ed. rev. e aum. Porto Alegre: Sergio Antonio Fabris Editor, 2003, p. 11.

${ }^{14}$ STRECK, Lenio Luiz. Bem jurídico e constituição: da proibição de excesso (übermassverbot) à proibição de proteção deficiente (untermassverbot) ou de como não há blindagem contra normas penais inconstitucionais.

Disponível
} 
Essa interpretação - bem como a aplicação do Direito - comprometida com a Constituição é a que deve existir com o novo horizontel pós-88, havendo íntima relação dos atos e decisões (de juízes ou de legisladores) com os Princípios e as Garantias da Pessoa.

O sistema de nulidades deve, por evidente, obedecer a tal entendimento constitucional e, com vistas ao que determinam os preceitos constitucionais, permitir um processo com foco no densificador valorativo que é o Devido Processo Legal.

Fauzi Hassan Choukr aponta o caminho constitucional com destaque e enfatiza qual é realmente a finalidade do sistema de nulidades:

é pelo sistema de nulidades e, mais exatamente, pelo método da convalidação dos atos desconformes que se tem uma baliza, um termômetro do grau dos valores emanados pela CR e pela CADH para o processo penal. $^{15}$

Isso porque a nulidade é uma forma de preservar o Devido Processo Legal e os demais Princípios, e Garantias, previstos na Constituição ou mesmo que estejam, nesta, implícitos.

Neste ponto, cabível o que prega o autor Alberto Binder:

Em um Estado de Direito, o julgamento de uma pessoa, em conseqüência do qual ela pode perder sua liberdade, às vezes pelo resto de sua vida, esta regulado por um conjunto de princípios historicamente configurados e que têm como finalidade proteger os cidadãos das arbitrariedades cometidas ao longo da história por esse poder de encarcerar os concidadãos que se conhecem ao Estado. ${ }^{16}$

Interessante notar a seqüência do que diz o autor, "um princípio está garantido só quando seu descumprimento gera a invalidez do ato que o violou. Para garantir o cumprimento desses princípios, estabelecem-se requisitos para os atos processuais". ${ }^{17}$

Nos termos exatos do que diz Alberto Binder, estes requisitos são as formas dos atos que estão previstas e indicadas na legislação. A cadeia lesada com uma nulidade é ampla.

em:<http://leniostreck.com.br/index.php?option=com_docman\&ltemid=40> Acesso em: 05 fev. 2009.

${ }^{15}$ CHOUKR, Fauzi Hassan. Código de Processo Penal. Comentários Consolidados e Crítica Jurisprudencial. $4^{a}$ edição reestruturada, revista, ampliada e atualizada. Rio de Janeiro: Lumen Juris, 2010, p. 838.

${ }^{16}$ BINDER, Alberto M. O Descumprimento das formas processuais. Elementos para uma crítica da teoria unitária das nulidades no processo penal. Rio de Janeiro: Lumen Juris, 2003, p. 41.

${ }^{17}$ BINDER, Alberto M. O Descumprimento das formas processuais. Elementos para uma crítica da teoria unitária das nulidades no processo penal. Rio de Janeiro: Lumen Juris, 2003, p. 42. 
Viola-se a forma, que é prevista em lei, logo a legislação é atacada. Também não escapa a garantia e, por fim, viola-se um Princípio e, assim, todo o sistema no qual este está incluído.

Constatada tal cadeia, fica evidente que quando uma nulidade ocorre à lesão é muito mais grave do que apenas a que se enxerga superficialmente. Ora, se os princípios foram levados à Carta Democrática para permitir o Devido Processo Legal que não viole a Dignidade e permita Justiça, quando se ataca uma forma são estes os valores em jogo.

\section{O NOVO HORIZONTE PROCESSUAL CONSTITUCIONAL E SEUS REFLEXOS NO SISTEMA DE NULIDADES}

O sistema de nulidades que vigora no Brasil tem uma função essencial que é a de assegurar o cumprimento do Devido Processo Legal. Por isso, quando existe uma atipicidade processual em algum ato jurídico deve ser ponderado, sempre, qual a garantia ou o princípio que foi violado.

A nulidade não afeta, porquanto, a lei, viola o princípio ou a garantia e, por consequinte, viola o Devido Processo e as possibilidades de Justiça no caso concreto. Além disso, um outro ferimento que se abre quando existe uma nulidade é a segurança jurídica. A este propósito, o verve ensinamento do jurista argentino Sergio Gabriel Torres:

En cuanto a su función, encontramos en las nulidades um fin Inmediato y otro mediato. El primero se relaciona con el buen orden del proceso y el restante, con los derechos de la sociedad y los del imputado, a los que intenta conciliar, con la finalidad de preservar en última instancia el debido proceso y la inviolabilidad de la defensa en juicio; es decir, que la nulidad es el guardián de las garantías constitucionales en el proceso penal. Creemos finalmente, que si bien es cierto que la existencia de formalidades en el proceso imponen demoras en la tramitación de expedientes y provocan gastos e inconvenientes, no debemos olvidar que existe un interés superior que las justifica: la seguridad jurídica ${ }^{18}$.

O preço que se paga por um Estado de Direito que deve(ria) buscar ser democrático inclui o respeito incondicional aos princípios estabelecidos por serem não apenas aqueles erigidos como valores sociais relevantes, mas também os densificadores de uma rota para a Justiça alinhada à Dignidade Humana.

Por constituírem os princípios e as garantias valores importantes, até autoaplicáveis, não cabe o desrespeito a tais postulados, inclusive voz acertada que "o nível e a força dessa garantia se descobre através da

\footnotetext{
${ }^{18}$ TORRES, Sergio Gabriel. Nulidades em el proceso penal. $2^{\mathrm{a}}$ ed. actu. y ampl. Buenos Aires:
} Ad hoc, 1993, p. 32. 
jurisprudência sobre nulidades. Essa jurisprudência é a outra face do sistema de garantias e assinala o nível de cumprimento dos princípios próprios de um processo adequado ao regime constitucional". ${ }^{19}$

Ora, não se pode cogitar um Estado Democrático com um processo penal arbitrário e não se pode falar em Justiça e Dignidade se nem o Devido Processo é respeitado. Logo, a função do sistema de nulidades é a de guardião dos princípios e das garantias.

Os atos servem para que as partes se manifestem adequadamente, não havendo tais atos ou tendo sido sua ocorrência maculada, não se dá a correta voz a defesa ou a acusação. Ao juiz, direcionam-se atos nos quais deve haver plena justificação para o réu e para a sociedade sobre seus atos e decisões. Também há atos que devem ser realizados para evitar o abuso do Estado sobre 0 acusado.

Não se respeitando tais construções, o processo não pode ser considerado um palco justo e vivo na busca por uma verdade processual e sim uma mostra de arbítrio e falta de compromisso com a democracia e seus valores fundantes.

Elio Fazzalari ${ }^{20}$ expunha que o processo tem por finalidade a sentença resultante de um processo em contraditório. A existência de um vício em um dos atos que precedem a decisão contamina todos os outros, passando de um ato a outro, até contaminar $o$ ato final.

O processo deve, com efeito, se realizar e os princípios devem ser protegidos, até porque não existe possibilidade jurídico válida de obter uma decisão justa sem o cumprimento mínimo da legislação processual pois foi ela elaborada para permitir a pretendida conclusão sobre a Verdade.

Portanto, é a Constituição Federal um repositório que, tendo um ato realizado em descumprimento, deve ensejar a invalidade de um ato processual penal praticado.

Percebe-se, a tempo de salvaguardar muitos processos, a íntima relação entre as nulidades, a Constituição Federal e as características doutrinárias ${ }^{21}$

\footnotetext{
${ }^{19}$ BINDER, Alberto M. O Descumprimento das formas processuais. Elementos para uma crítica da teoria unitária das nulidades no processo penal. Rio de Janeiro: Lumen Juris, 2003, p. 43.

${ }^{20}$ FAZZALARI, Elio. Istituzioni di Diritto Processuale. $8^{a}$ ed. Padova: Cedam, 1996, p. 90.

${ }^{21}$ GRINOVER, Ada Pellegrini. GOMES FILHO, Antonio Magalhães. FERNANDES, Antonio Scarance. As nulidades do processo penal. $11^{\text {a }}$ edição revista, atualizada e ampliada. São Paulo: RT, 2009, p. 19.
} 
atribuídas às nulidades absolutas (presunção de prejuízo ${ }^{22}$, não convalidação, possibilidade de reconhecimento de ofício e decorrente de violação de norma de ordem pública ou princípio ${ }^{23}$ ) na intenção de se proteger o Devido Processo.

Essas características - embora presentes na literatura e estabelecidas como formas de proteção processual - não são vistas, em sua plenitude nos tribunais brasileiros.

Em especial, e mesmo por ser a medida afeta ao presente trabalho, a análise do prejuízo se mostra como fundamental em razão da ampla convergência que todos os vícios do sistema de nulidades têm sobre ele.

E o cerne desse visão afastada da doutrina é o fato de se usar como "vigamestra" do sistema de nulidades um conceito aberto e impreciso.

\section{O PREJUÍZO NAS NULIDADES ABSOLUTAS}

Uma varredura na doutrina nacional mostra que se usa a expressão "prejuízo", mas sem qualquer explicação detalhada ou contextualizada ao processo penal e a sua importância.

A palavra prejuízo tem dois significados distintos e que convivem dentro da tentativa de significação, o primeiro é de um juízo prévio, um pré-juízo e o segundo é de desvantagem.

Interessante a percepção de que no universo das nulidades as duas significações coexistem e esvaziam de sentido a palavra, porque se fala em prejuízo a todo o momento, mas não se explica que é um juízo anterior que faz acreditar que, naquele caso, a parte prejudicada com a ilegalidade realizada pelo Estado não fica em desvantagem.

A doutrina desconsidera outro fator importante, pois quando se julga com a utlização do prejuízo, o julgador não percebe que está avocando para si uma situação que não the pertence, qual seja, a compreensão e a percepção do prejuízo que é sofrida pela parte e causada, aí sim, pelo julgador ou por outro funcionário público.

\footnotetext{
${ }^{22}$ LOPES JR., Aury. Direito Processual Penal e sua Conformidade Constitucional. V. 2. Rio de Janeiro: Lumen Juris, 2009, p. 398.

${ }^{23}$ OLIVEIRA, Eugênio Pacelli de. Curso de Processo Penal. 13a edição. Rio de Janeiro: Lumen juris, 2010, p. 807.
} 
A omissão de algum ato, a prática de forma diversa da lei ou, ainda mais grave, de forma que não se respeite algum preceito constitucional ataca as possibilidades de manifestações, segurança, provas, justificações e até mesmo a credibilidade da Justiça, pois se enxerga a possibilidade de a lei ser violada por quem tem um único dever de fazer com que a vontade do legislador ordinário e constitucional seja cumprida.

A tipicidade processual é o que se espera no processo, visto que a defesa e a acusação se preparam para isso e o ato em desconformidade legal é uma grave e repentina afronta a todo um exercício de ampla defesa ou de pretensão acusatória. Logo, são estas partes que podem notar e identificar a desvantagem e o preconceito que sofrem no curso procedimental.

É importante verificar que essa noção de desvantagem quando decorrente de violação de princípio ou garantia, pelo volume de interesse que tem a norma desrespeitada, não necessita prova do prejuízo, ou seja, as partes lesadas não têm a necessidade de demonstração dos efeitos que a ilegalidade estatal causou.

Renata Jardim da Cunha Rieger e Guilherme Rodrigues Abraão expõe as características das nulidades absolutas, citando o prejuízo presumido:

é possível identificar que tais nulidades violam normas que tutelam verdadeiro interesse público ou ainda, como referido, acabam por violar determinado princípio constitucional. Assim, justamente por apresentar relevante interesse público e ser tida como insanável (pois não se convalida, e muito menos é convalidada pela preclusão), tais nulidades podem ser declaradas de ofício pela autoridade judicial e em qualquer grau de jurisdição (ou ainda, é claro, por meio de provocação da parte interessada), não sendo necessário demonstrar-se qualquer prejuízo, pois se trata de prejuízo presumido ${ }^{24}$

Cumpre anotar que essa presunção de prejuízo nas nulidades absolutas não é uma qualidade aleatória e sem fundamento, nem pode ser considerada um entendimento doutrinário, constituíndo-se, sim, em uma qualidade inerente a violação de um princípio ou garantia constitucional que, pelo interesse que tutela, não poderia ser violado sem causar um forte estremecimento ao processo criminal e aos direitos das partes.

\footnotetext{
${ }^{24}$ RIEGER, Renata Jardim da Cunha. ABRÃO, Guilherme Rodrigues. Nulidades no Processo Penal brasileiro. Regras gerais do Código de Processo Penal e do Projeto 156. A necessária leitura do sistema de invalidades à luz das categorias próprias do Processo Penal. Disponível em http://jusvi.com/artigos/42493. Acesso em 20/05/2011.
} 
O raciocínio é complexo em razão de ter sido construída uma cultura jurisprudencial de que existe uma possibilidade de normas serem violadas sem o sentido buscado por elas seja maculado.

Aury Lopes Jr prega que "não necessita demonstração de prejuízo, pois manifestou ou presumido, como preferem alguns" 25 .

Ocorre que a jurisprudência, a despeito do que pretende a doutrina, não aceita o entendimento de que quando princípios fundamentais ou garantias são violadas a parte que alega não deve mostrar o prejuízo, sendo uma decisão constante a que se permite convalidar a atipicidade constitucional sob 0 argumento de que não se demonstrou o prejuízo.

Cabem algumas críticas neste ponto, que é nevrálgico.

Primeiro, cabe lembrar que o magistrado quando declara o prejuízo o faz como se não tivesse causado a pretensa nulidade, como se pudesse prever as conseqüências da atipicidade e como se compreendesse totalmente a estratégia das partes. Isso porque alega que não houve prejuízo sem saber o que a defesa ou a acusação pretendiam no processo.

Segundo, que há situações a longo prazo no processo criminal que tem etapas usadas pela defesa ou pela acusação como estratégia, não sendo possível que, quando o juízo descumpra uma disposição legal, se possam expor tudo que foi idealizado no início, sob pena de um prejuízo duplo e muito maior, consistente na ferida pela nulidade e pela obrigação de se expor o prejuízo sofrido para a parte revelando, assim, seus passos seguintes.

Mais do que isso, exigir uma demonstração de prejuízo passa pela possibilidade de a defesa ou a acusação fazerem uma exposição total de suas teses para a outra parte e para o julgador e, mesmo assim, obterem um resultado insatisfatório já que o discurso permite qualquer interpretação.

\subsection{A Exigência de Prova de Prejuízo nas Nulidades Absolutas}

O Supremo Tribunal Federal, em julgado da Primeira Turma, proferiu acórdão utilizando o famoso brocardo do "Pas de nullité sans grief" e não anulou um processo em que o advogado do réu, defensor público, sequer foi intimado para a audiência de instrução:

EMENTA HABEAS CORPUS. PROCESSO PENAL. TENTATIVA DE ROUBO. PROCEDIMENTO. INTERROGATÓRIO. FALTA DE INTIMAÇÃO DA DEFENSORIA PÚBLICA E ASSISTÊNCIA AO RÉU POR MEIO DE DEFENSOR AD HOC. NULIDADE.

\footnotetext{
${ }^{25}$ LOPES JR., Aury. Direito Processual Penal e sua Conformidade Constitucional. V. 2. Rio de Janeiro: Lumen Juris, 2009, p. 384.
} 
PREJUÍZO NÃO DEMONSTRADO. 1. A demonstração de prejuízo, a teor do art. 563 do CPP, é essencial à alegação de nulidade, seja ela relativa ou absoluta, visto que, conforme já decidiu a Corte, "o âmbito normativo do dogma fundamental da disciplina das nulidades - pas de nullité sans grief - compreende as nulidades absolutas" (HC 81.510, Rel. Min. Sepúlveda Pertence, $1^{\mathrm{a}}$ Turma, unânime, DJ de 12/4/2002). 2. Ordem indeferida.

(HC 99053, Relator(a): Min. DIAS TOFFOLI, Primeira Turma, julgado em 21/09/2010, DJe-228 DIVULG 26-11-2010 PUBLIC 2911-2010 EMENT VOL-02440-01 PP-00009)

O fudamento dessa decisão é o Habeas Corpus 81.510 julgado também pela Primeira Turma do Supremo em 11/12/2001 em que foi relator o Ministro Sepúlveda Pertence que ementou o seguinte:

2. O âmbito normativo do dogma fundamental da disciplina das nulidades - pas de nullité sans grief - compreende as nulidades absolutas - qual, no caso, a incompetência do Juizado Especial se a falta do inquérito policial - que não é garantia de defesa -, e a seqüência do procedimento da L. 9.099/95, perante Juíza que, na comarca, era a titular exclusiva da jurisdição penal, nenhum prejuízo em concreto acarretou à defesa do paciente

Dentro deste paradigma, cumpre verificar dois pontos. O inicial é que esse brocardo francês é usado para qualquer que seja a interpretação do julgador. Todavia, não é um princípio ou uma garantia, é uma disposição de natureza processual penal anterior à Constituição Federal de 1988, pois data de 1941.

Esse brocardo está expresso na norma processual brasileira da seguinte forma:

Art. 563. Nenhum ato será declarado nulo, se da nulidade não resultar prejuízo para a acusação ou para a defesa.

Observa-se que quando da publicação da norma processual, a Constituição em vigência à época, a de 1937, sequer falava em Devido Processo Legal. Logo, a norma processual é empoeirada e antiga, sendo que não passou por uma adequação pós-constituição.

Interessante notar que - no âmbito internacional - diversos Códigos de Processo Penal, como o argentino $^{26}$, o paraguaio $^{27}$, o espanhol ${ }^{28}$ e 0

\footnotetext{
${ }^{26}$ Codigo Procesal Penal de la Nacion. Disponível em:

http://www.csjn.gov.ar/cmf/cod_procesal_penal.html. Acesso em 10/05/2011.
} 
português ${ }^{29}$ não falam sobre o prejuízo ou sobre sua demonstração, sendo que nas Constituição de todos estes Estados, mesmo as que foram promulgadas depois dos Códigos, falam em um processo Devido e democrático.

O libro I do codigo de procedimimento penal da Espanha fala no artigo 69 que os atos podem ser anulados quando existir norma descrevendo a sanção de invalidade. O Código de Processo Penal português segue a mesma linha de descrição da nulidade para o ato. O código procesal penal argentino diz que o ato será nulo quando não observar as normas prescritas.

Aury Lopes Jr expõe a cicatriz quando fala que existe "baixo nível de conformidade constitucional desse diploma de 1941"30, portanto, empoeiradas são as regras aplicáveis as nulidades processuais penais, ainda mais por não se contabilizar a nova ordem democrática e o Devido Processo.

Ligado a este prejuízo como condição da nulidade, outro dispositivo processual que trata do prejuízo nas nulidades é o artigo 566:

Art. 566. Não será declarada a nulidade de ato processual que não houver influído na apuração da verdade substancial ou na decisão da causa.

Fala-se em nulidade vinculada a apuração da verdade substancial ou na decisão da causa, ou seja, o prejuízo não é apenas a parte, mas também à decisão da causa. A crítica a esta dispositivo é vultoso já que se pretende que exista alguém capaz de analisar, no presente, como será o comportamento futuro do julgador ao analisar o processo. Isso passa pelo

Concluí-se, diante da sistemática processual, que a ilegalidade praticada deve causar desvantagem - comprovada - para a parte e para a decisão da causa, de outra forma não haverá, no Brasil, declaração de nulidade.

A jurisprudência dos Tribunais consolidou esse entendimento e passou a não reconhecer nulidades em diversos casos graves de desrespeito a legislação, causando uma situação na qual a violação da lei cometida pelo juiz era

\footnotetext{
${ }^{27}$ Codigo Procesal Penal de Paraguay. Disponível em: http://www.unifr.ch/ddp1/derechopenal/legislacion/l_20080616_73.pdf. Acesso em 07/04/2011.

${ }^{28}$ Codigo de Procedimiento Penal espanõl. Disponível em: http://www.oas.org/juridico/spanish/chi_res8.pdf. Acesso em 06/06/2011.

${ }^{29}$ Código de Processo Penal Português. Disponível em: http://www.legix.pt/docs/CPP.pdf. Acesso em 01/06/2011.

${ }^{30}$ LOPES JR., Aury. Direito Processual Penal e sua Conformidade Constitucional. V. 2. Rio de Janeiro: Lumen Juris, 2009, p. 381.
} 
evidente e inegável enquanto que aa violação da lei da qual foi acusado o réu pode resultar em absolvição.

No entanto, como visto, nem todas as nulidades precisam de demonstração de prejuízo, posto que as absolutas tem prejuízo presumido, sendo que a compreensão difundida nos Tribunais de que todas as nulidades devem ser provadas é decorrente de um transplante feito do processo civil para o penal.

\subsection{A Constituição Federal e as Nulidades Processuais Penais}

Necessário perceber que nem a disciplina das nulidades se limita ao Código de Processo Penal (pois a Constituição Federal contempla normas) e nem 0 conceito de prejuízo do art. 563 (e o Pas de nullité sans grief) é a norma mais atualizada a ser tratada como paradigma do sistema de nulidades.

A Carta trouxe normas constitucionais com nulidade cominada na hipótese de desrespeito. È o caso do art. 93, inciso IX:

IX todos os julgamentos dos órgãos do Poder Judiciário serão públicos, e fundamentadas todas as decisões, sob pena de nulidade, podendo a lei limitar a presença, em determinados atos, às próprias partes e a seus advogados, ou somente a estes, em casos nos quais a preservação do direito à intimidade do interessado no sigilo não prejudique o interesse público à informação; (Redação dada pela Emenda Constitucional n 45, de 2004)

Também foi elevada aquela que prevê o Devido Processo Legal:

LIV - ninguém será privado da liberdade ou de seus bens sem o devido processo legal;

Essas normas evidentemente definem direitos e são consideradas garantias da pessoa, logo, incluem-se na imediatidade de aplicação por força de disposição constitucional.

Eis a norma:

$\S 1^{\circ}$ - As normas definidoras dos direitos e garantias fundamentais têm aplicação imediata. 
Dentro deste quadro, anota-se que a Supremacia da Constituição em relação à norma processual é vitoriosa no debate contra a norma infra, o que mostra no que deve se pautar o magistrado quando escolhe anular ou não, que é o Devido Processo e seus densificadores e não o simples conceito de prejuízo.

Mais que isso, a norma constitucional comina nulidade em casos específicos, não sendo possível que a lei antiga e inferior restrinja o mandamento constitucional, sob pena de se ferir a própria hierarquia constitucional, pois não anular quando a Carta manda anular é criar lei e interpretação hermenêutica impossível, sob o aspecto técnico.

Não obstante tal questão é imperativo notar que se antes o importante para decretação da nulidade era a demonstração de prejuízo para a parte que influisse na decisão, com a nova constituição cabe verificar que o que é analisado é a eficácia conferida aos princípios e garantias constituintes do Devido Processo.

Houve, com efeito, uma alteração de foco de análise, pois o objeto não pode ser o prejuízo, pelo menos não nas nulidades absolutas por violarem principios e garantias, e sim a efetividade dos princípios e garantias já que são estes a única forma de se atingir uma decisão correta e justa, perante a Constituição Federal.

\subsection{Os Primeiros Precedentes Relevantes sobre Prova Impossível de Prejuízo}

Dentro da superação do empoeirado quadro de valores processuais préconstitucionais em relaçao a 88, cumpre expor que a idéia do magistrado era (tentar) demonstrar que o ato (viciado) não causou prejuízo às partes e a busca da verdade real.

Em reação ao entendimento eminentemente legal de nulidades, o Supremo Tribunal Federal em julgado relatado pelo Ministro Sepulveda Pertence, no Habeas Corpus 69142, julgado em 1992, decidiu que há casos, de nulidades absolutas, em que a prova do prejuízo (como não poderia deixar de ser) é impossível.

Diante de tal constatação, os Ministros da Primeira Turma entenderam que a defesa (ou qualquer pessoa) poderia provar algo tão abstrato como uma conseqüência futura de um acontecimento no presente.

Eis o julgado: 
Ampla defesa: frustração do direito a sustentação oral no julgamento da apelação. Viola a garantia da ampla defesa o julgamento de apelação criminal, não obstante ja deferido o pedido de adiamento formulado pelo defensor do acusado. Frustrado, assim, o direito da parte a sustentação oral, e nulo o julgamento, não cabendo reclamar para declara-lo a prova impossivel de que, se utilizada aquela oportunidade legal de defesa, outra teria sido a decisão do recurso. (HC 69142, Relator(a): Min. SEPÚLVEDA PERTENCE, PRIMEIRA TURMA, julgado em 11/02/1992, DJ 10-04-1992 PP-04799 EMENT VOL01657-03 PP-00417 RTJ VOL-00140-03 PP-00926)

Nota-se que foi considerado, na decisão, que ninguém poderia saber no que resultaria a sustentação oral, sendo importante o fato de que o tribunal afastou um princípio vigente, qual seja, o da ampla defesa.

Em 2005, o mesmo relator, na mesma Turma, em caso semelhante, decidiu da mesma forma em outras duas oportunidades:

EMENTA: 1. Defesa: Defensoria Pública: ausência de intimação pessoal da pauta de julgamento do recurso em sentido estrito: nulidade absoluta: precedentes. 2. Sustentação oral frustrada pela ausência de intimação da pauta de julgamento: demonstração de prejuízo: prova impossível (v.g., HC 69.142, $1^{\mathrm{a}}$ T., 11.2.92, Pertence, RTJ 140/926). Frustrado o direito da parte à sustentação oral, nulo o julgamento, não cabendo reclamar, a título de demonstração de prejuízo, a prova impossível de que, se utilizada aquela oportunidade legal de defesa, outra teria sido a decisão do recurso. (RHC 85443, Relator(a): Min. SEPÚLVEDA PERTENCE, Primeira Turma, julgado em 19/04/2005, DJ 13-05-2005 PP-00019 EMENT VOL-02191-02 PP-00282)

EMENTA: I. STF - HC - Competência originária. Não pode o STF conhecer originariamente de questões suscitadas pelo impetrante - fixação do regime integralmente fechado e de execução provisória da pena - que não foram submetidas ao Superior Tribunal de Justiça, ao qual, em conseqüência, não se pode atribuir a alegada coação. II - Defesa - Entorpecentes - Nulidade por falta de oportunidade para a defesa preliminar prevista no art. 38 da L. 10.409/02: demonstração de prejuízo: prova impossível (HC 69.142, $1^{\mathrm{a}}$ T., 11.2.92, Pertence, RTJ 140/926; HC 85.443, $1^{\mathrm{a}}$ T., 19.4.05, Pertence, DJ 13.5.05). Não bastassem o recebimento da denúncia e a superveniente condenação do paciente, não cabe reclamar, a título de demonstração de prejuízo, a prova impossível de que, se utilizada a oportunidade legal para a defesa preliminar, a denúncia não teria sido recebida. 
(HC 84835, Relator(a): Min. SEPÚLVEDA PERTENCE, Primeira Turma, julgado em 09/08/2005, DJ 26-08-2005 PP-00028 EMENT VOL-02202-2 PP-00366 LEXSTF v. 27, n. 321, 2005, p. 410-415)

No ano seguinte, em um caso de erro de procedimento, a Primeira Turma novamente decidiu pela nulidade sem demonstração de prejuízo, porquanto seria o mesmo de prova impossível:

EMENTA: Defesa: devido processo legal e contraditório (CF, art. $5^{\circ}$, LIV e LV): manifesta nulidade decorrente da abertura de prazo para alegações finais antes de encerrada a instrução, tendo sido, após a apresentação delas, inquiridas outras testemunhas, sobre as quais, por isso não foi dada oportunidade à Defesa para manifestar-se: demonstração de prejuízo concreto: prova impossível. Conseqüente anulação do processo a partir da audiência em que inquirida a última das testemunhas, abrindo-se novo prazo para requerimento de diligências e alegações finais ( $L$. 8.038/90, art. 10 e seg.). (RE 467658, Relator(a): Min. SEPÚLVEDA PERTENCE, Primeira Turma, julgado em 30/05/2006, DJ 25-08-2006 PP-00054 EMENT VOL-02244-06 PP01082 RTJ VOL-00201-03 PP-01185 LEXSTF v. 28, n. 333, 2006, p. 516-520)

Interessante notar a precisão consideração feita no voto do ministro relator no RE 767658 quando este diz que "seria impossível, no caso, a demonstração de prejuízo concreto: não há como saber se, aberta a oportunidade para as alegações escritas, depois de finda a instrução, outra seria o conteúdo delas e sua influência sobre sua decisão".

Portanto, segundo o entendimento pós-constitucional do Supremo, ficou claro que em casos nos quais a nulidade decorre de violação de princípio ou garantia, exigir uma demonstração concreta e prova ampla de prejuízo é retalhar a própria Constituição, pois seria basear a segurança democrática contraditório e de devido processo em um exercício de futurologia.

Ruiu, com efeito, o primeiro conceito de necessidade de prova do prejuízo no processo penal pós-constitucional e, se diz, pos-constitucional em razão de não existir tal precedente de prova impossível de prejuízo no paradigma anterior. Mais que isso, antes não se falava nos princípios fundamentais, ao passo que, atualmente, são estes os verdadeiros reguladores do processo.

\subsection{Precedentes de Prejuízo Presumido}

Em outra frente que não a da prova impossível de prejuízo quando da prática de ilegalidade pelo Estado no processo, há um entendimento no Supremo Tribunal Federal de que muitas situações (conforme a doutrina já pregava) de que o vício do ato gera um prejuízo presumido. 
Em razão de ter existido uma mudança no ponto magnético do sistema de nulidades processuais penais, as quais passaram a ser nulidades processuais penais constitucionais pela influência dos princípios e garantias, é necessário se constatar que - havendo desrespeito ao instrumento democrático - parte-se de uma noção dentro da qual violar princípio ou garantia causa um vício e, pela importância destes instrumentos, tal vício não pode ser desimportante.

O Ministro Marco Aurélio no RCH 95140 declinou que "A formalidade válida é essencial à valia do processo, ressaltando-se a presunção de direito do prejuízo quando não observada". Expõe-se o julgado:

PROCESSO PENAL - DENÚNCIA - AUDIÇÃO PRÉVIA DO ACUSADO - FORMALIDADE - NATUREZA. A defesa prévia do acusado, antecedendo o recebimento da denúncia, é formalidade essencial imposta por norma imperativa. PROCESSO PENAL DENÚNCIA - AUDIÇÃO DO ACUSADO - PREJUÍZO. O simples fato de olvidar-se elemento próprio ao devido processo legal gera a presunção de prejuízo, que, depois de prolatada decisão condenatória, fica certificado mediante instrumento público formalizado pelo Judiciário. (RHC 95140, Relator(a): Min. MARCO AURÉLIO, Primeira Turma, julgado em 29/09/2009, DJe-030 DIVULG 18-02-2010 PUBLIC 19-02-2010 EMENT VOL-02390-02 PP-00226)

Conforme exposto, existe uma presunção de prejuízo em razão da violação de um preceito que constitua o Devido Processo Legal, cabendo, neste momento, considerações para evitar o excesso no discurso.

Inicialmente, refere-se tal julgado aos "itens" que fazem parte do Devido Processo Legal. Estes são, sem dúvida, os princípios e as garantias. Logo, não é qualquer norma que tem consigo a noção de prejuízo presumido em seu descumprimento, mas apenas aquelas que são consideradas geradoras de nulidades absolutas.

Outra questão a ser trazida é que houve condenação, o que agravou (e não causou de forma autonoma) o prejuízo sofrido pelo réu.

Isso faz a jurisprudência se acertar com a doutrina pós-constituição.

No mesmo ano, a Ministra Carmem Lúcia, em Habeas Corpus relatado pelo Ministro Marco Aurélio, decidiu pela nulidade de um processo sob o argumento do prejuízo presumido:

HABEAS CORPUS - AMPLITUDE. O habeas corpus não sofre qualquer peia. Para ser tido como adequado, basta apontar-se ilegalidade a alcançar o direito de ir e vir do paciente e haver órgão acima daquele que praticou o ato. NULIDADE - ESPÉCIE. Presentes a nulidade relativa e a absoluta, cumpre assentar que, 
no tocante a esta última, a passagem do tempo mostra-se neutra. PROCESSO PENAL - DENÚNCIA - AUDIÇÃO PRÉVIA DO ACUSADO - FORMALIDADE - NATUREZA. A defesa prévia do acusado, antecedendo o recebimento da denúncia, é formalidade essencial imposta por norma imperativa. PROCESSO PENAL DENÚNCIA - AUDIÇÃO DO ACUSADO - PREJUÍZO. O simples fato de olvidar-se elemento próprio ao devido processo legal gera a presunção de prejuízo, que, depois de prolatada decisão condenatória, fica certificado mediante instrumento público formalizado pelo Judiciário. (HC 96864, Relator(a): Min. CÁRMEN LÚCIA, Relator(a) p/ Acórdão: Min. MARCO AURÉLIO, Primeira Turma, julgado em 20/10/2009, DJe-237 DIVULG 17-12-2009 PUBLIC 18-12-2009 EMENT VOL-02387-04 PP-00664)

Apresentadas nos dois acórdãos acima o fato de que a lei não é sem valor (mais do que a lei, os princípios e as garantias não podem ser considerados vazios), logo, o imperativo legal não pode ser descumprido sem sanção alguma, já que, fosse o descumprimento da forma sempre carente de sanção, simplesmente não haveria razão de se ter lei processual.

Em outro julgado, este da Segunda Turma do STF, o relator, Ministro Cezar Peluso, votou pela presunção de prejuízo quando da condenação do acusado, aplicando paradigma diverso daquela acima, da Primeira Turma:

EMENTAS: 1. COMPETÊNCIA CRIMINAL. Habeas corpus. Impetração contra decisão de ministro relator do Superior Tribunal de Justiça. Indeferimento de liminar em habeas corpus. Caso de constrangimento ilegal manifesto. Conhecimento admitido, com atenuação do alcance do enunciado da súmula $\mathrm{n}^{\circ} 691$. Precedente. O enunciado da súmula 691 do Supremo não o impede de, tal seja a hipótese, conhecer de habeas corpus contra decisão do relator que, em habeas corpus requerido ao Superior Tribunal de Justiça, indefere liminar. 2. AÇÃO PENAL. Processo. Defesa. Cerceamento. Caracterização. Inquirição de testemunhas da acusação. Não intimação do defensor constituído, nem de defensor público ou ad hoc. Caso de nulidade absoluta. Prejuízo inerente à condenação do réu. Precedentes. Desnecessidade, porém, de renovação do processo, à conta de extinção da punibilidade por prescrição. $\mathrm{HC}$ concedido de ofício para pronunciá-la. É, desde $\mathrm{O}$ ato viciado, absolutamente nulo o processo em que, inquiridas testemunhas da acusação sem prévia intimação do defensor constituído, tenha sido o réu condenado.

(HC 97427, Relator(a): Min. CEZAR PELUSO, Segunda Turma, julgado em 02/06/2009, DJe-118 DIVULG 25-06-2009 PUBLIC 2606-2009 EMENT VOL-02366-03 PP-00570) 
Neste, a condenação gerou a presunção do prejuízo e noutro o afastamento de oportunidade foi o responsável pela presunção de prejuízo, agravada pela condenação.

O Ministro Joaquim Barbosa, no ano de 2009, relatou Habeas Corpus no qual tratou da falta de necessidade de se comprovar o prejuízo sofrido:

EMENTA: Habeas corpus. Ação Penal. Réu defendido por defensor dativo. Ausência de intimação pessoal do defensor. Ofensa ao disposto no art. 370, $\S 4^{\circ}$, do CPP. Nulidade absoluta. Precedentes. É entendimento reiterado desta Corte que a prerrogativa de intimação pessoal dos defensores de réus de ação penal é inerente aos defensores dativos, por força do art. $370, \S 4^{\circ}$, do Código de Processo Penal, e decorrente da própria Constituição, que assegura o direito à ampla defesa em procedimento estatal que respeite as prerrogativas do devido processo legal. Precedentes. A falta de intimação pessoal do defensor dativo qualifica-se como causa geradora de nulidade processual absoluta, sendo desnecessária a comprovação, nesta hipótese, do efetivo prejuízo para que tal nulidade seja declarada. Precedentes. Ordem concedida. (HC 98802, Relator(a): Min. JOAQUIM BARBOSA, Segunda Turma, julgado em 20/10/2009, DJe-223 DIVULG 26-11-2009 PUBLIC 27-11-2009 EMENT VOL-02384-03 PP-00543)

Na mesma linha, seguiram outros acórdãos do STF com a presunção de prejuízo em razão da falta de possibilidade de demonstração da desvantagem:

EMENTA: AÇÃO PENAL. Processo. Tráfico de entorpecentes. Procedimento especial. Interrogatório prévio ao juízo de recebimento da denúncia. Ato não realizado. Realização apenas na audiência de instrução e julgamento. Condenação dos réus. Prejuízo presumido. Nulidade processual. Processo anulado desde a denúncia, inclusive. HC concedido para esse fim. Precedentes. Inteligência dos arts. 38, caput, e 41, caput, da Lei $n^{\circ}$ 10.409/2002. A inobservância do rito previsto no art. 38, caput, da Lei $\mathrm{n}^{0}$ 10.409/2002, que exige o interrogatório prévio do denunciado por crime de tráfico de entorpecentes, implica nulidade do processo, sobretudo quando tenha sido condenado o réu (HC 88836, Relator(a): Min. CEZAR PELUSO, Segunda Turma, julgado em 08/08/2006, DJ 06-10-2006 PP-00067 EMENT VOL-02250-04 PP-00669 LEXSTF v. 28, n. 336, 2006, p. 474-480 RT v. 96, n. 856, 2007, p. 512-515)

O voto do Ministro Cezar Peluso demonstra que a violação de princípio enseja nulidade absoluta e, para alguns atos que teriam possibilidade de utilização de argumentos, apresentação de versões ou de outros elementos de defesa, o prejuízo não pode ser provado: 
"Tenho, porém, que o prejuízo oriundo da supressão do prévio interrogatório é evidente, embora de demonstração impossível. Não há como saber se, diante do teor do interrogatório, teria o juízo deixado de receber a denúncia ou desclassificado a imputação feita aos pacientes".

Ministro Ricardo Lewandowski adotou mesmo entendimento em Habeas Corpus por ele relatado:

EMENTA: HABEAS CORPUS. PROCESSUAL PENAL. DEFESA PRÉVIA. LEI DE TÓXICOS. ART. 38 DA LEI 10.409/02 INOBSERVÂNCIA. EXISTÊNCIA DE PREJUÍZO PARA A AMPLA DEFESA. I - A inobservância do rito instituído pela Lei 10.409/02, art. 38, resulta na nulidade do processo penal desde 0 recebimento da denúncia, inclusive. II - Ordem concedida.(HC 87347, Relator(a): Min. RICARDO LEWANDOWSKI, Primeira Turma, julgado em 29/08/2006, DJ 27-10-2006 PP-00050 EMENT VOL-02253-03 PP-00412 RTJ VOL-00200-02 PP-00938)

Eis o voto:

"Diante disso, não há como deixar de constatar que se registrou ofensa ao direito de defesa do acusado. A nulidade apontada, com efeito, independe de comprovação de prejuízo por tratar-se de direito indisponível. Isso porque qualquer assertiva quanto ao resultado da peça acusatória, quando esta já tenha sido recebida, sem que tenha havido oferecimento de defesa prévia, é matéria meramente especulativa". (Precedentes - HC 84.835/SP. Rel Min. Sepulveda Pertence; RHC - MC 86.535/SP. Rel. Min. Cezar Peluso; HC - MC 87.438/SP. Rel. Min. Eros Grau).

Potente foi o argumento utilizado por partir da premissa do direito indisponível e, portanto, que orbita sobre interesses públicos (estes causadores de nulidades absolutas) - o qual não pode ser desconsiderado pelas partes ou pelo Estado-juiz por força de uma conclusão evidente, qual seja, a de que se demonstrar uma prejuízo por ato que não ocorreu é matéria de especulação, haja vista o fato de não se poder prever o que seria alegado e nem se poderia fazer as partes alinhavarem suas estratégias para demonstrar o prejuízo. 


\section{CONSIDERAÇÕES FINAIS}

A inauguração de uma nova ordem constitucional trouxe diversos benefícios. Garantiu direitos das pessoas e, como forma de protegê-los, emitiu comandos normativos com ônus ao Estado.

No estudo feito demonstra com o uso da doutrina a virada interpretativa que se operou com a constituição e o reflexo direto no sistema de invalidades no processo penal.

Para tanto, elucidou-se inicialmente os vícios do sistema de nulidades, como a idéia de que concretizar uma nulidade apenas beneficia o réu, o fato de que se considera a forma processual um exagero burocrático e que falta de precisão terminológica permite uma abertura interpretativa ampla.

Em um item à frente, especificou-se que a Carta trouxe novas fórmulas processuais, além de um foco diverso do anterior, sendo o novo construído sobre a eficácia das garantias da pessoa e nos princípios.

No tópico seguinte, foi possível observar o conceito de prejuízo e as qualidades que orbitam sobre ele, inclusive a compreensão doutrinária sobre as características das nulidades absolutas.

Com o uso de jurisprudências, abordou-se decisões sobre prejuízo impossível se ser provado e prejuízo presumido como focos que alteram a necessidade de se demonstrar o prejuízo com a prática ilegal de ato pelo Estado-juiz.

Diante de tais observações, demonstrou-se que existe uma nova fonte que reflete o sistema de nulidades, qual seja, a carta fundamental, densificada pelo Devido Processo e pela Dignidade.

\section{REFERÊNCIAS BIBLIOGRÁFICAS}

ARAGONESES ALONSO, P. (1997) Proceso y Derecho Procesal. 2a. ed. Madri: Edersa.

CONSTANTINO, L. S. (2006) Nulidades no processo penal. Porto Alegre: Verbo Jurídico.

COUTURE, E. J. (2002) Fundamentos del derecho procesal civil. $4^{\circ}$ ed. Buenos Aires: Euros.

FAZZALARI, E. (1996) Istituzioni di Diritto Processuale. $8^{a}$ ed. Padova: Cedam. 
FERNANDES, A. S. (2010) Processo Penal Constitucional. 6ª edição. São Paulo: RT.

FERNANDES, P. S. L.; FERNANDES, G. B. (2002) Nulidades no processo penal. 5a. ed. São Paulo: Malheiros.

GRINOVER, A. P. GOMES FILHO, A. M.. FERNANDES, A. S. (2009) As nulidades do processo penal. $11^{\text {a }}$ edição revista, atualizada e ampliada. São Paulo: RT,.

LOPES Jr. A. (2008) Direito Processual Penal e sua Conformidade Constitucional. Volume I. $3^{\mathrm{a}}$ edição. Rio de Janeiro: Lumen juris.

LOPES Jr. A. (2009) Direito Processual Penal e sua Conformidade Constitucional. Volume II. $1^{\mathrm{a}}$ edição. Rio de Janeiro: Lumen juris.

MEDEIROS, F. M. (1987) Nulidades do processo penal. 2. ed. Rio de Janeiro: Aide.

LOUREIRO, A. T. (2010) Nulidades e Limitação do Poder de Punir. Rio de Janeiro: Lumen juris.

NASSIF, A. (2001) Considerações sobre nulidades no processo penal. Porto Alegre: do Advogado.

NUCCl, G. de S. (2008) Código de Processo Penal Comentado. $8^{\circ}$ edição, revista, atualizada e ampliada. São Paulo: RT., pg. 500.

OLIVEIRA, E. P. (2010) Curso de Processo Penal. $13^{\mathrm{a}}$ edição. Rio de Janeiro: Lumen juris.

RANGEL DINAMARCO, C. (1990) A Instrumentalidade do Processo. São Paulo: Malheiros.

RIEGER, R. J. C. ABRÃO, G. R. Nulidades no Processo Penal brasileiro. Regras gerais do Código de Processo Penal e do Projeto 156. A necessária leitura do sistema de invalidades à luz das categorias próprias do Processo Penal. Disponível em http://jusvi.com/artigos/42493. Acesso em 20/05/2011.

SARLET, I. W. (2008) Dignidade da Pessoa Humana e Direitos Fundamentais na Constituição Federal de 1988. $2^{\mathrm{a}}$ edição. Porto Alegre: do Advogado.

THUMS, G. (2006) Sistemas processuais penais: tempo, tecnologia, domologia e garantismo. Rio de Janeiro: Lumen juris.

TORRES, S. G. (1993) Nulidades em el proceso penal. $2^{\text {a }}$ ed. actu. y ampl. Buenos Aires: Ad hoc.

TOVO, P. C. TOVO, J. B. M. (2008) Nulidades no Processo Penal Brasileiro. Rio de Janeiro: Lumen juris. 